\title{
ENTOMOLOGY
}

\section{Genus Delplanqueia Leraut, 2001 and D. inscriptella (Duponchel, 1836) (Lepidoptera, Pyralidae) in Italy}

\author{
M. Pinzari, ${ }^{1}$ M. Pinzari² \\ ${ }^{1}$ Department of Biology, University of Roma Tor Vergata, Rome; ${ }^{2}$ Amateur entomologist, Rome, Italy
}

\begin{abstract}
To verify the presence in Italy of Delplanqueia inscriptella, today accepted as a separate species from $D$. dilutella, we carried out the study of the historical collections of Carlo Prola and Federico Hartig and new material that was recently collected in central Italy. Both species are present in continental Italy and Sicily while only $D$. inscriptella in Sardinia. The bibliographic reconstruction and the examination of the Hartig's specimens that revealed the presence of Delplanqueia cortella, for a long time considered a corso-sardinian endemism, is not reflected: the specimens in Hartig's collection with $P$. cortella placement are indeed Pempeliella matilella.
\end{abstract}

Correspondence: Manuela Pinzari, Department of Biology, University Tor Vergata of Rome, via della Ricerca Scientifica 1, 00133 Rome, Italy. Tel.: +39.06.72595950 - Fax: +39.06.72595965.

E-mail: manuela.pinzari@uniroma2.it

Key words: Delplanqueia, dilutella, inscriptella, cortella, Pyralidae.

Acknowledgments: The authors would like to thank Dr. Roberto Casalini (Museo Civico di Zoologia di Roma) and Dr. Emanuele Piattella (Museo di Zoologia dell'Università di Roma La Sapienza) for allowing the study of the specimens of Prola's and Hartig's collections, respectively.

Contributions: the authors contributed equally.

Conflict of interest: the authors declare no potential conflict of interest.

Funding: none.

Dedication: the article is dedicated to Anna Appolloni.

Received for publication: 13 March 2019.

Revision received: 18 July 2019.

Accepted for publication: 7 August 2019.

${ }^{\circ}$ Copyright: the Author(s), 2019

Licensee PAGEPress, Italy

Journal of Entomological and Acarological Research 2019; 51:8168

doi:10.4081/jear.2019.8168

This article is distributed under the terms of the Creative Commons Attribution Noncommercial License (by-nc 4.0) which permits any noncommercial use, distribution, and reproduction in any medium, provided the original author(s) and source are credited.

\section{Introduction}

The genus Delplanqueia by Leraut (2001) includes four species: dilutella (Denis \& Schiffermüller, 1775), inscriptella (Duponchel, 1836), cortella (Constant, 1884) and nobilella (Ragonot, 1887).

Delplanqueia dilutella and D. inscriptella have been confused for a long time. At present Leraut (2014) mentioned them as two different species and, therefore, D. subornatella (Duponchel, 1837 ) as a synonym of dilutella.

In this new framework, several researchers have begun to study the distribution of $D$. inscriptella. In Europe, it was found in Malta (Asselbergs et al., 2008), England (Agassiz, 2015), Denmark (Buhl et al., 2016), Switzerland (Schmid, 2016), Belgium (Slootmaekers et al., 2018), Germany (Wittland and Seliger, 2016), Slovakia (Pastorális et al., 2017), Balkan Peninsula (Plant et al., 2017) and Iberian Peninsula and Balearic Islands (Ylla et al. 2019).

In Italy, according to "Check list della fauna d'Italia" (Bassi et al., 1995), the species cortella and dilutella are attributed to the genus Pempeliella. Pempeliella cortella is cited for northern Italy and Sardinia, while dilutella for the north of Italy and the isles, Sicily and Sardinia. Recently, P. dilutella, but still considered as inscriptella, was also recorded in an ongoing survey of the Lepidoptera fauna in central (Pinzari, 2009, Pinzari et al., 2010; Pinzari and Sbordoni, 2013; Pinzari et al., 2013a, 2013b, 2015; Pinzari, 2016a, 2016b; Pinzari et al., 2016a, 2016b, 2017a, 2017b, 2018a, 2018b, 2019a, 2019b; Pinzari, 2019; Pinzari \& Pinzari, 2019) and southern Italy (Scalercio, 2016). According to Leraut (2001), to clarify our understanding of the distribution of these species in Italy and also verify the goodness of the historical faunistic information in the literature of the last century, we studied dissecting recentlycollected specimens in our collection and other private collections of central Italy and examining specimens from all Italian regions in ancient collections in "Museo civico di Zoologia di Roma" and "Museo di Zoologia dell'Università la Sapienza di Roma".

Here, we provided information on the geographical distribution of Delplanqueia group in Italy and newly showed the presence of $D$. inscriptella in Italy.

\section{History and distribution of Delplanqueia group in Italy before Leraut (2014)}

In the Checklist of Italian fauna, Bassi et al. (1995) mentioned D. cortella in the north of Italy and Sardinia, while dilutella (Denis \& Schiffermüller, 1775) (=dilutella Hübner, 1796=ador- 
natella Treitschke, 1835=subornatella Duponchel, 1837=integella Staudinger, 1859=integrella Wocke, 1871) in the north, Sicily and Sardinia.

Speidel et al. (2013) in Fauna Europaea online (accessed 2019) provide data on: $D$. cortella in Corsica, Sardinia and Italian mainland; D. inscriptella in Spain and France mainland, and Channel Is.; D. dilutella in all parts of Europe and everywhere in Italy. Pempeliella matilella was also recorded in Corsica and Sardinia (Leraut, 2001). Leraut (2014) provided distribution data on Delplanqueia dilutella and D. inscriptella illustrating the distribution on maps of Europe including the continental Italy without details and bibliographic references.

In the following text we reported the precise citations of our studied species mentioned in the past literature. The species subornatella and dilutella were attributed in the past to different genera Pempelia or Pempeliella or Delplanqueia by different collectors. For this reason and simplicity, here, we introduce these species without specifying the genus.

\section{subornatella (Duponchel, 1837).}

VALLE D’AOSTA: Pempelia subornatella, Gressoney (Curò, 1880); Parco Mont Avic, 1 ô, prati sopra Volla, $1500 \mathrm{~m}$ ca., 25.VII.1994 (lux); (Baldizzone, 1996). PIEMONTE: Terme di Valdieri, luglio-agosto, Pempelia subornatella Dup. (Turati E. and Verity R., 1911). Magnoni-sentiero per la Colma, 500-600 m, 21.V.2003. Colle degli Eremiti, 560 m, 7.IX.2005 (lux). La Benedicta, Cascina Moglioni, $800 \mathrm{~m}$ ca., 27.VIII.2003 (lux). Capanne inferiori, località Gli Olmi, 758 m, 10.VI.2003 (lux); 19.VI.2003 (lux); 8.VII.2003 (lux); 27.VIII.2003 (lux). Capanne superiori, sentiero per il Rio Lischeo, $850 \mathrm{~m}, 22$. VII.2005. Delplanqueia subornatella (Duponchel, 1837) Sauter W. det. (Baldizzone et al., 2013). TRENTINO-ALTO ADIGE: Brennero, North and South(Hartig, 1956). Provincia di Bolzano, Pempeliella subornatella (Burmann, 1995). Venosta: Media Venosta 8.IX.(19)29, Laces-Latsch 30.VII, Latschander multiple moths. 1., 3. e 6.VI.(19)29 (Astfaller B. leg.); Juval frequent to light) from the middle of V-VI, isolated from the middle of VIII-IX (Reitberger $\mathrm{H}$. leg.); Stava-Staben 26.V.(19)30, Naturno-Naturns 1-24.V.34 (Astfaller B. leg.); ibid. freq. 12-15.IX.36 (Hartig F. leg.); 5.VI.51; Val d'Adige: Ora-Auer 12.IV.(19)53 (Kappeler R. leg., Burmann K. det.); Matarello, 1 đ̃, 26.VIII.(19)28 and 19. IX.(19)33 (Perini T. leg.); Zona Gardesana: Nago, 1 q 30.V.(19)30 (Dannehl F. leg.); Gardone 1 \% 16.VIII.1933 (Turati E. leg.); Val Sarca infer.; Val d'Isarco: Chiusa-Klausen, VI.(19)05 (Moebius E. leg.); Dolomiti: Val Popena (Mann J. \& Roggenhofer A. leg.); (Hartig, 1958). FRIULI-VENEZIA GIULIA: Provincia di Trieste, Pempeliella subornatella (Burmann, 1995). EMILIA ROMAGNA: Pempelia subornatella Dup., S. Varano (FC), Gianelli G. det., Ladino (Forlì, FC), Gianelli G. det., maggio e agosto, (Zangheri P. leg.) (Zangheri, 1923, 1950). SICILIA: Casteldaccia e dintorni (PA), V-VII, Pempelia subornatella Dup. (Mariani, 1939).

\section{dilutella (Denis \& Schiffermüller, 1775).}

LOMBARDIA: Pempelia adornatella, giugno, Alzate (CO) (Turati 1879). PIEMONTE: Terme di Valdieri, luglio-agosto (Turati and Verity, 1911). Venaria R., 20.V.1930, boschi di Mirafiori, 20.V.1927 (Della Beffa, 1941). Valdieri, Riserva Speciale dello Juniperus phoenicea, $900 \mathrm{~m}$ ca., 11.IX.1998, 10.VII.1999, 12.VII.1999 (lux), Pempeliella dilutella (Denis \& Schiffermüller, 1775); (Baldizzone, 2005). Campi della Marca, 630 m, 30.VI.2010 (lux); Colle degli Eremiti, 560 m, 31.V.2004; Sentiero per Cascina Nespolo, 600 m ca., 31.V.2002; Capanne inferiori, località I Foi, 770 m, 2.VII.2008 (lux); Capanne inferiori, località Gli Olmi, 758 m, 12.VII.2002 (lux); 9.VI.2003 (lux); 19.VI.2003 (lux) 27.VIII.2003 (lux); 14.VI.2004 (lux), Delplanqueia dilutella (Denis \& Schiffermüller, 1775); (Baldizzone et al., 2013). TRENTINO-ALTO ADIGE: Brennero, N. e S. (Hartig, 1956). Venosta: NaturnoNaturns, at light, VI.(19)35 (Klimesch J. leg.); Sette Comuni: Lavarone VII.(19)33 (Anonymous collector); Brenta e Paganella:

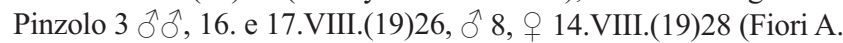
leg.); Gruppo orientale: Tures-Taufers, not frequent (Weiler J. leg.);

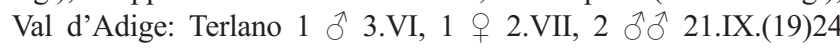
(Dannehl F. leg.); ibid. 23.V (Ostheleder L. leg.); S. MaurizioMoritzing (Hellweger M. leg.); Castel Firmiano-Sigmundskron, 1 ふૈ, 21.VI, 7.VIII.(19)25 (Dannehl F. leg.); Bolzano (Mann J. leg.); Montagna-Montan 29.VIII.(19)54 (Kappeler R. leg., Burmann K. det.); S. Michele IX.(19)34 (Anonymous collector); Trento $1 \hat{\jmath}$ 29.VI.(19)26 (Trener G.B. leg.); Matarello 14, 22 e 29.VI, 28.VIII, 8.IX.(19)28 e 8.VIII.(19)31 (Perini T. leg.); Val d'Isarco: Bressanone (Hellweger M. leg.); Ponte Isarco-Waidbruck (Schawerda K. leg.); Campodazzo-Atzwang 13.VI.54 (Burmann K. leg.); Zona gardesana: Eremitaggio-Torri, found isolatedin VI.(19)40, S. Vigilio 1 ㅇ 9.VIII.1942 (Hartig F. leg.); Alpi Sarentine: Collalbo-Klobenstein 1 of 4.VII.(19)30, found isolated from the beginning of VI to the middle of VII.(19)47 (Hartig F. leg.); Avelengo-Hafling 12.VII.(19)31 (Hager K. leg.); (Hartig, 1958). Provincia di Bolzano, Pempeliella dilutella=adornatella (Burmann, 1995). Pempeliella dilutella, Pomarolo (TN) (Huemer, 2002). Neumarkt (Egna) (BZ), Kurtinig (Cortina) (BZ) (Huemer, 2004). FRIULI-VENEZIA GIULIA: Provincia di Trieste, Pempeliella dilutella=adornatella (Burmann, 1995). Alesso andTagliamento (Udine), Pempeliella dilutella (Deutsch, 2006). Area of the Dealpine rivers Meduna and Tagliamento (Friuli-Venezia Giulia, northern-Italy), Pempeliella dilutella (Huemer, 1997). 1 ô, (gen. praep. Fazekas I., No. 2722), Carso Goriziano, Marcottini (GO), 6.VI.1989, Morin L. leg (Fazekas, 1996). VENETO: Valle Vecchia di Caorle, Venezia, Pempeliella dilutella (Denis \& Schiffermüller, 1775), (Huemer and Morandini, 2008). UMBRIA: San Faustino (TR), Narni (TR), Pempeliella dilutella (Pinzari et al., 2010). 1 क, Assisi (PG), Colcaprile, Via Mosciole, 450 m, 21.V.2005, Zerunian Z. \& I. leg. 1 §., Monte Subasio (PG), Mortaro Grande, 1200 m, 16.VI.2015 (gen. praep. PIRA 330, M. Pinzari), Zerunian Z. leg, Pempeliella dilutella (Pinzari et al., 2016a). LATIUM: Pempelia dilutella, Fondi, S. Anastasia, 1 స̃, 1-12.VIII, Predota C. leg (Hartig, 1939). Cittaducale (RI), Cardito, Prola C. leg.; Monte Cagno e dintorni, Borbona (RI) Fraz. Vallemare, località Colle Marcone, $1121 \mathrm{~m}$, Pian Mattano, 1100 m, Posta (RI), Fraz. Villa Camponeschi, località Colle Petruccio, 1000 m (Pinzari et al., 2010). Tenuta Presidenziale di Castelporziano (RM), Pempeliella dilutella (Pinzari et al., 2017a). EMILIA ROMAGNA: località Bosco di Ladino (Forlì, FC), August, Pempeliella dilutella Hb., Turati E. det., Zangheri P. leg (Zangheri, 1923, 1950). Pempelia dilutella Hb., Perino (Frazione di Coli, PC), 19.IX (Roberti et al., 1965). CALABRIA: Contrada Li Rocchi, Rende (CS), 205 m, 14.V.2014, Delplanqueia dilutella (Scalercio, 2016). SARDINIA: Santoru, 8.VI; Aritzo, 4-20.VII; Belvì, 6.VIII; Desulo, 7.VII, Pempelia dilutella; (Hartig and Amsel, 1951). SICILY Pempelia dilutella, V. VIII (Mariani, 1939). Mistretta, Monte Neviera, Pempelia dilutella (Zerny, 1943).

\section{Pempelia cortella (Constant, 1884).}

SARDINIA: Sa Casa 24-29.VII; Aritzo 9-27.VII; Piano di Sadali 5.VII; Strada per Desulo 8.VII. Pempelia cortella Const. (Hartig and Amsel, 1951).

\section{Pempeliella matilella Leraut, 2001.}

SARDINIA: Paratypes: $1 \hat{\jmath}$, Italie, Sardaigne, Aritzo, “dint. Cant. Sa Casa", 950 m, 24.VII.36 (conte F. Hartig) (gen. praep. Leraut P., $\mathrm{n}^{\circ}$ 6639; MNHN, Paris); trois femelles, memes coordon- 
nees, une femelle, Sardaigne, 3.VIII.1936 (H.G. Amsel); (Leraut, 2001).

\section{Material examined and species identification}

We studied the specimens from central Italy in the collections ("coll." hereafter) of Maltzeff P. (Rome, at present, it is included in Pinzari collection), Pinzari (Rome) and Zerunian (Assisi), and from other Italian localities in the collections of Prola C. and Hartig F. preserved respectively in Museo civico di Zoologia di Roma ("MCZR" hereafter) and Museo di Zoologia dell'Università la Sapienza di Roma ("MZUR" hereafter).

For the taxonomic identification, specimens were identified either after external habitus and by dissections of the genitalia using characters reported by Leraut (2001) and recent authors (Buhl et al., 2016; Schmid, 2016; Plant et al., 2017; Slootmaekers et al., 2018). Genital parts were glycerol-preserved into microtubes whose ends were closed with vinyl glue easily soluble in water: the microtubes were put under the specimens themselves. For the species identification based on habitus, we took into account wing colour, pattern and wingspan ("wingspan", "WS" hereafter) of each specimen. For the study of genital parts, we calculated: in males, the ratio between the lengths of cornutus and aedeagus ("CA ratio" hereafter); in females, the ratio between the length of the short and the long signa bands ("S ratio" hereafter), and the mutual position of the two genital structures. The genitalia features were directly measured on photographs which we expressed in percentage (Table 1). They were compared between inscriptella and dilutella, using a Mann-Whitney U test.

To verify the relationship between the ancient specimens of museum collections and the past literature, we recorded the collo- cation ("colloc." hereafter) of the species (Hartig's collection, boxes no. 17a and 18a; Prola's collection, original collocation unknown) and the presence of determination cards under the specimens. After our study, all specimens of the collection of F. Hartig (MZUR) and C. Prola (MCZR) have been returned to the museums and placed in a new collocation on basis of our species determination. We added another ID card under the original card to each specimen.

To show an updated distribution of Delplanqueia group in Italy, we mapped the collecting sites of the examined material showing also the localities of specimens cited in literature but for which it was not possible to examine the moths.

\section{Results}

During our study, we identified correctly the species and grouped the specimens following the recent determination by Leraut (2001). All specimens of Pempeliella subornatella Duponchel, 1837 were identified as Delplanqueia dilutella (Denis \& Schiffermüller, 1775) and all specimens of Pempeliella dilutella (Denis \& Schiffermüller, 1775) were classified as Delplanqueia inscriptella (Duponchel, 1836). Below is the list of the studied specimens grouped according to the new determination.

\section{Delplanqueia dilutella (Denis \& Schiffermüller, 1775).}

LOMBARDIA: $1 \lesssim$ (gen. praep. PIRA 469, M. Pinzari), Italia sept. (Monte) Bisbino (CO), 15.VI.(19)08, coll. Kruger, with label of species determination "Pempelia subornatella Dup., Kruger Geo. C.” (MCZR). PIEMONTE: 1 đ̋ (gen. praep. PIRA 492, M. Pinzari), colloc. in subornatella, Piemonte, Alpi Cozie, Oulx, 14.VIII.1936 (legit absent), (MZUR). 1 ๙ (gen. praep. PIRA 523, M. Pinzari),

Table 1. Species identification based on habitus and genitalia features.

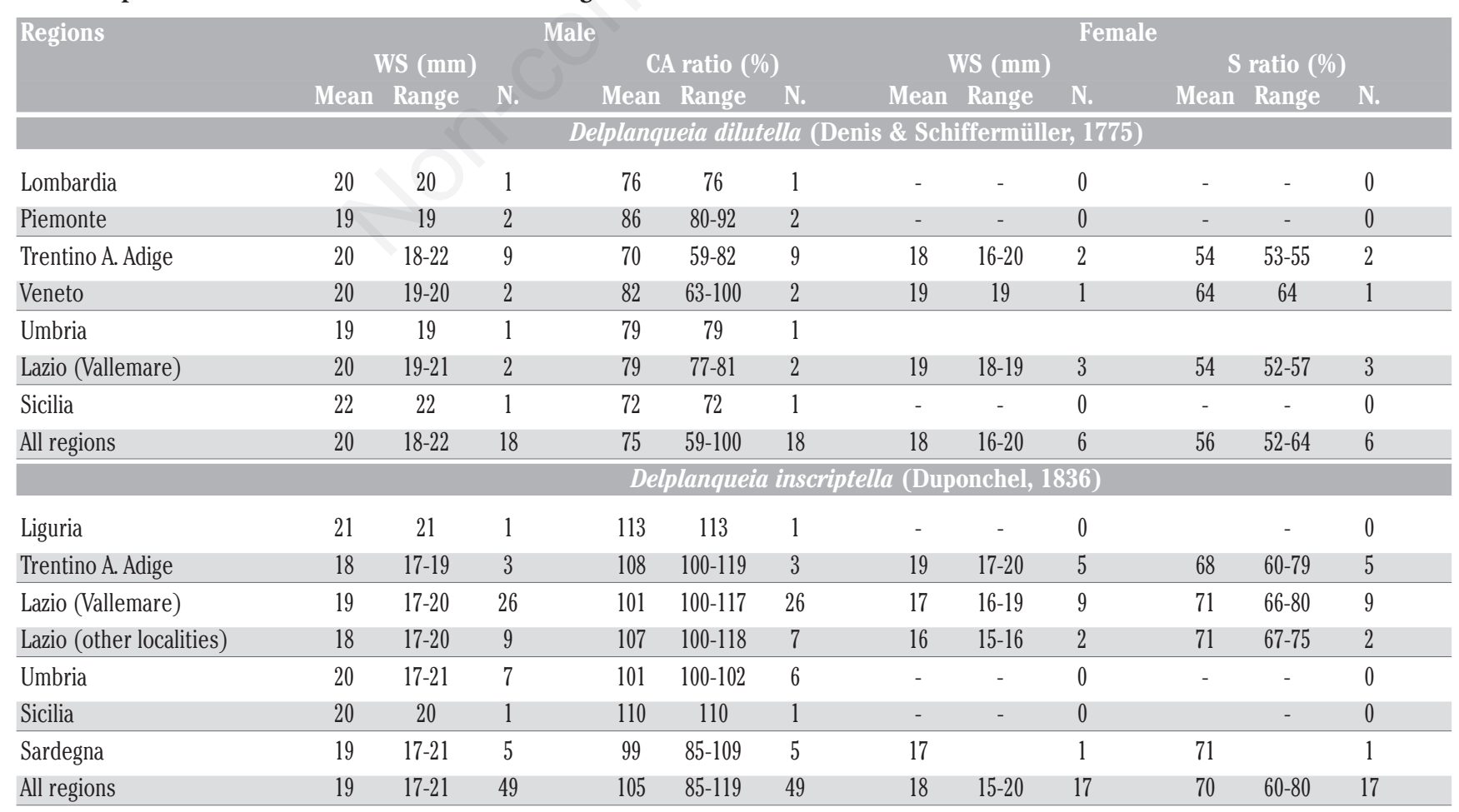

WS, wingspan; CA ratio, the ratio between the lengths of cornutus and aedeagus; $\mathrm{S}$ ratio, the ratio between the length of the short and the long signa bands. 
Italy Albarasca di Stazzano, 18.VIII.(19)82, E. Berio leg. (MCZR); VENETO: 1 $\widehat{\jmath}$ (gen. praep. PIRA 475, M. Pinzari), colloc. in dilutella, Lago di Garda, Torri Benaco, 2.VI.40; 1 (gen. praep. PIRA 500, M. Pinzari), colloc. in P. dilutella, idem, 6.VI.1940, 1 § (gen. praep. PIRA 501, M. Pinzari), colloc. in $P$. dilutella, idem, 8.VI.1940; 1 (gen. praep. PIRA 472, M. Pinzari), colloc. in $P$. dilutella, Lago di Garda, San Vigilio, 9.VIII.(19)42, Hartig leg (MZUR). TRENTINO-ALTO ADIGE: 1 o (gen. praep. PIRA 486, M. Pinzari), colloc. in P. subornatella, Trentino, Gardone,

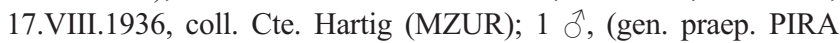
510, M. Pinzari), colloc. in P. subornatella, Val Venosta, Naturno, 550 m, 1.V.1934, 4 ふ઼ઈ (gen. praep. PIRA 484, PIRA 508, PIRA 509, PIRA 511, M. Pinzari), colloc. in subornatella, idem, 21.V.1934, 1 ऊ (gen. praep. PIRA 512, M. Pinzari), colloc. in subornatella, idem, 12-15.IX.1936, 1 §े (gen. praep. PIRA 483, M. Pinzari), colloc. in subornatella, idem, 15.IX.1936, coll. Cte. Hartig (MZUR). 1 ` (gen. praep. PIRA 494, M. Pinzari), colloc. in P. subornatella, Matarello, Trento, Italia, 19.IX.1933, 1 ( (gen. praep. PIRA 489, M. Pinzari), colloc. in P. subornatella, idem, 2531.X.1936, T. Perini leg (MZUR). UMBRIA: 1 ઈ (gen. praep. PIRA 524, M. Pinzari), Orvieto, S. Faustino, 4.VIII.58 (1958), Prola C., (MCZR). LATIUM: Vallemare (RI), 1 $\widehat{\jmath}$, Colle Marcone, $1121 \mathrm{~m}$, 13.V.2011 (gen. praep. PIRA 279, M. Pinzari), M. Pinzari leg., 1 오, (gen. praep. PIRA 528, M. Pinzari); Lazio dint. di Posta(RI), Villa Camponeschi, località Colle Petruccio, 1000 m, 1-8.VIII.2001, 1 ㅇ, (gen. praep. PIRA 526, M. Pinzari), idem, 25.VIII.2001, 1 o, (gen. praep. PIRA 525, M. Pinzari), idem, 20.VIII.2002, A. Zilli leg., (MCZR). ABRUZZO: 1 त, Abruzzo, Magliano dei Marsi, $700 \mathrm{~m}$, Prola C., 26.V.(19)80 (MCZR). SICILIA: 1 $\delta$ (gen. praep. PIRA 485, M. Pinzari), colloc. in subornatella, Sicilia, Palermo, 4.VIII.193(sic!), Dannehl F. leg. (MZUR).

\section{Delplanqueia inscriptella (Duponchel, 1836).}

LIGURIA: 1 (gen. praep. PIRA 470, M. Pinzari), colloc. in cortella, Alpi Marittime, Carmo Langan, 14.VIII.(19)50, Prola C. leg. (MCZR). TRENTINO ALTO-ADIGE: 1 (gen. praep. PIRA 507, M. Pinzari), colloc. in dilutella, Collalbo, Bolz, $1200 \mathrm{~m}$, 14.VI.1947, 2 우 (gen. praep. PIRA 473, PIRA 495, M. Pinzari), colloc. in dilutella, idem, 16.VI.(19)47, 1 o (gen. praep. PIRA 474, M. Pinzari), 1 (gen. praep. PIRA 506, M. Pinzari), Colloc. in dilutella, idem, 16.VII.(19)47; Hartig F. leg. (MZUR). $1 \lesssim$, (gen. praep. PIRA 504, M. Pinzari), colloc. in dilutella, Matarello, Trento, Italia, 8.VIII.(19)31, 1 o, (gen. praep. PIRA 505, M. Pinzari), colloc. in dilutella, idem, 1-5.VIII.1936, 1 + (gen. praep. PIRA 481, M. Pinzari), colloc. in dilutella, idem, 25-31.8.1936, Perini T. leg. (MZUR). UMBRIA: $1 \lesssim$ (gen. praep. PIRA 471, M. Pinzari), colloc. in dilutella, Umbria, Narni, VIII.56, 2 ठठ (gen. praep. PIRA 467, PIRA 533, M. Pinzari), 4.9.(19)58, 1 \%, idem,

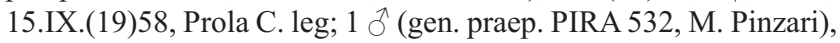
Orvieto, 5.VIII.(19)52, Prola C. leg; (MCZR). 1 §, Monte Subasio (PG), Mortaro Grande, 1200 m, 16.VI.2015 (gen. praep. PIRA 330, M. Pinzari), 1 đ (gen. praep. PIRA 420, M. Pinzari), idem, 10.VI.2017, Zerunian Z. leg., 1 đ (gen. praep. PIRA 498, M. Pinzari), Assisi (PG), località Colcaprile Via Mosciole, $450 \mathrm{~m}$, 21.V.2005, Zerunian Z \& I. leg. LATIUM: 1 + , colloc. in dilutella, Cittaducale (RI), Cardito, 18.V.(19)49, 1 ô, idem, 14.IX.(19)49, 1

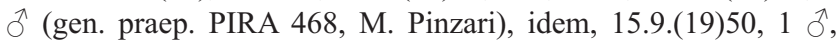
idem, 25.IX.(19)58, Prola C. leg (MCZR). 1 ô (gen. praep. PIRA 476, M. Pinzari), colloc. in dilutella, Lazio, Palo (RM), 24.V.(19)40, Hartig F. leg (MZUR). 1 đ (gen. praep. PIRA 479, M. Pinzari), colloc. in dilutella, Lazio, Fondi (LT), S.ta Anastasia, 312.VIII.1937, Predota C. leg (MZUR). $2 \hat{\jmath} \widehat{\partial}$, Lazio, dint. di Posta (RI), Villa Camponeschi, località Colle Petruccio, $1000 \mathrm{~m}$, 20.VIII.2002, 1 § (gen. praep. PIRA 529, M. Pinzari), idem,
25.VIII.2002, 1 $\lesssim$ (gen. praep. PIRA 527, M. Pinzari), 1 (gen. praep. PIRA 531, M. Pinzari), idem, 26.VIII.2002 (MCZR), Zilli A. leg. Vallemare, Borbona (RI), 1 đ (gen. praep. PIRA 3, M. Pinzari), Colle Marcone, $1121 \mathrm{~m}, 22$. VII.1989, 1 đ (gen. praep. PIRA 449, M. Pinzari), Colle Marcone, 1121 m, 5.VIII.1989, 1 ô, idem, 10.VIII.1989, 1 $\widehat{~(g e n . ~ p r a e p . ~ P I R A ~ 451, ~ M . ~ P i n z a r i), ~ i d e m, ~}$ 25.VIII.1989, $2 \widehat{\jmath}$, (gen. praep. PIRA 442, PIRA 458, M. Pinzari), idem, 27.VI.1998, 1 , (gen. praep. PIRA 55, M. Pinzari), idem, 5.VII.1997, 2 $\widehat{\jmath}$, idem, 5.VIII.2003, 2 우, idem, 7.VIII.2003, $1 \hat{\jmath}$, idem, 8.VIII.2003, $1 \hat{\jmath}$, idem, 18.VIII.2003, $1 \hat{\jmath}$, (gen. praep. PIRA 466, M. Pinzari), idem, 2.VIII.2005, 1 ㅇ, idem, 11.VIII.2005, 2 ऊ̂े, (gen. praep. PIRA 438, PIRA 446, M.

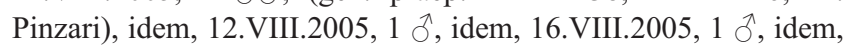
18.VIII.2005, 1 ते (gen. praep. PIRA 439, M. Pinzari), idem, 20.VIII.2005, $2 \hat{\jmath}$, idem, 25.VIII.2005, 1 $\hat{~(g e n . ~ p r a e p . ~ P I R A ~}$ 439, M. Pinzari), 1 ㅇ (gen. praep. PIRA 16, M. Pinzari), idem, 26.VIII.2005, 1 ô, idem, 30.VIII.2005, 1 q, idem, 16.VI.2006, 1

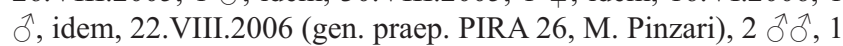

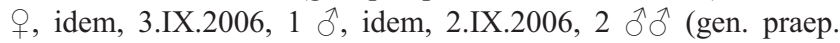
PIRA 454, M. Pinzari), idem, 3.IX.2006, 1 q, idem, 7.VII.2007, 2 đô (gen. praep. PIRA 456, M. Pinzari), idem, 8.VIII.2007, 1 ๙ (gen. praep. PIRA 452, M. Pinzari), idem, 11.VIII.2007, 2 ठૈ (gen. praep. PIRA 445, M. Pinzari), idem, 14.VIII.2007, 1 q (gen. praep. PIRA 463, M. Pinzari), idem, 15.VIII.2007, 1 q (gen. praep. PIRA 459, M. Pinzari), idem, 16.VIII.2007, 1 ô, idem, 17.VIII.2007, 1 ô, idem, 29.VIII.2007, 1 ô, idem, 28.V.2008, 2

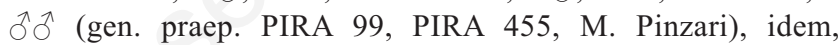
20.VI.2008, 1 o (gen. praep. PIRA 465, M. Pinzari), idem, 6.IX.2008, 1 q, idem, 3.VI.2009, 1 ઈ (gen. praep. PIRA 185, M. Pinzari), idem, 13.VI.2009, 1 ๙ (gen. praep. PIRA 457, M. Pinzari), idem, 28.VI.2009, $2 \widehat{\jmath} \widehat{\jmath}$, (gen. praep. PIRA 447, M. Pinzari), idem, 20.VII.2009, 1 †, idem, 16.VIII.2009, 1 q, idem, 19.VIII.2009, 1 \% , idem, 22.VIII.2009, 1 , (gen. praep. PIRA 464,

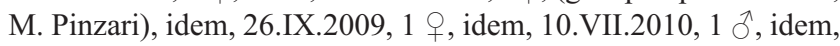
23.VII.2010, $1 \hat{\jmath}$, idem, 1.VIII.2010, 2 우, (gen. praep. PIRA 462, M. Pinzari), idem, 20.VIII.2010, 1 đ, idem, 13.V.2011 (gen. praep. PIRA 279, M. Pinzari), 1 ㅇ, idem, 8.VII.2011, 1 ㅇ, (gen. praep. PIRA 460, M. Pinzari), idem, 17.VIII.2011, 1 o, idem,

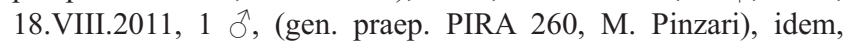

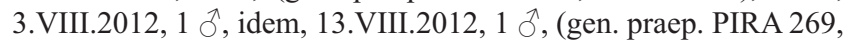

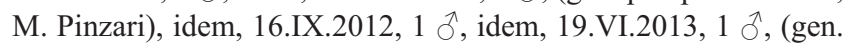
praep. PIRA 444, M. Pinzari), idem, 22.VIII.2013, $1 \hat{\jmath}$, (gen. praep. PIRA 453, M. Pinzari), idem, 20.IX.2013, 1 \%, idem,

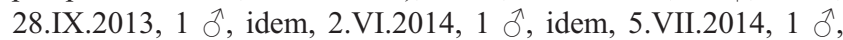

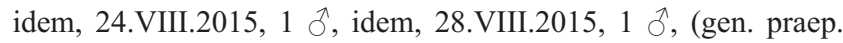

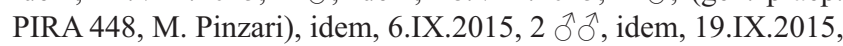
1 ㅇ, (gen. praep. PIRA 441, M. Pinzari), idem, 1.VII.2016, $2 \hat{\sigma} \bar{\sigma}$, (gen. praep. PIRA 443, M. Pinzari), idem, 24.VIII.2016, 1 \&, (gen. praep. PIRA 461, M. Pinzari), idem, 19.VIII.2017, 1 đે, idem, 25.VIII.2017; 1 $\widehat{\delta}$, (gen. praep. PIRA 450, M. Pinzari), 1 ๆ, Pian Mattano, 1100 m, 28.V.2017; 1 ô, Pian Zeidenti, 1300 m, 6.VI.2014; Pinzari M. leg. Roma litorale: Tenuta Presidenziale di Castelporziano (RM), 1 , at Bufolareccia: Casale dei Contumaci, La Fornace, 30.V-5.VI.2006, (gen. praep. PIRA 352, M. Pinzari), 1 ô (gen. praep. PIRA 346, M. Pinzari), 1 \&, Fontanile and Centro Inanellamento Tor Paterno, 12-17.VII.2006, 1 q (gen. praep. PIRA

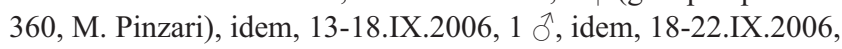
(gen. praep. PIRA 349, M. Pinzari), 1 \& (gen. praep. PIRA 357, M. Pinzari), idem, 22-27.IX.2006; Maltzeff P. leg. SARDINIA: $1 \lesssim$ (gen. praep. PIRA 503, M. Pinzari), colloc. in dilutella, Sardegna centrale, Aritzo (NU), 7.VII.1936, 1 đ̄ (gen. praep. PIRA 502, M. Pinzari), colloc. in dilutella, idem, 8.VII.1936, 1 § (gen. praep. PIRA 480, M. Pinzari), colloc. in dilutella, idem, 9.VII.1936, 1 え (gen. praep. PIRA 477, M. Pinzari), colloc. in dilutella, idem, 
20.VII.1936; 1 (gen. praep. PIRA 496, M. Pinzari), colloc. in dilutella, Sardegna centrale, Isili, 29.VII.1936; C.te Hartig F. leg. (MZUR); 1 क (gen. praep. PIRA 482, M. Pinzari), colloc. in dilutella, Ct. Fontanamela, 770 m, 3-4.VIII.1936; Hartig F. leg.

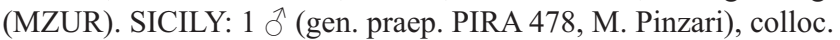
in dilutella, Sicilia, Zappulla (ME), 6.VI.1935, Mariani M. \& Hartig F, leg. (MZUR).

\section{Distinguishing the species}

\section{Males}

In both species, the phallus consists of a long cylindric aedeagus with projecting fingers and a vesica with one large cornutus. When the vesica is everted and the cornutus is clearly visible (Figure 1A) the cornutus is of about equal length to the aedeagus in D. inscriptella whereas in D. dilutella (Figure 1B) it tends to be shorter. The values of $C A$ ratio in dilutella were on average equal to $75 \pm 10 \%$ (Mean value $\pm S D$; Range: 59 to $100 \%$ ) and in
A
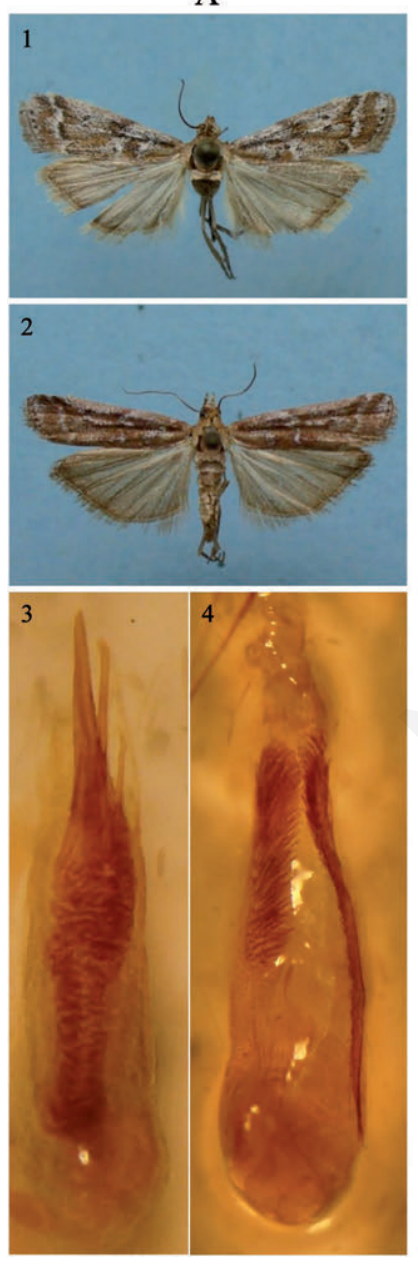

B
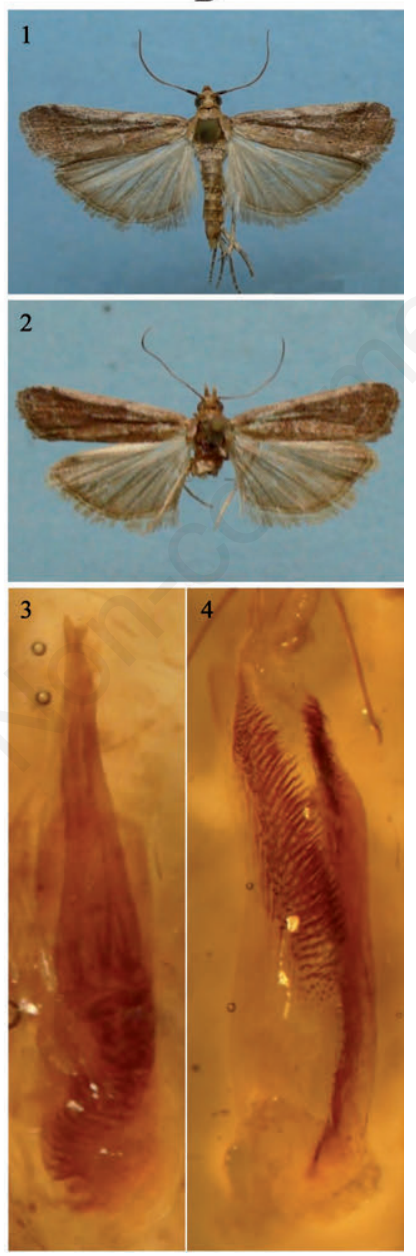

Figure 1. Delplanqueia dilutella (A): 1-3) Lazio, PIRA $279 \hat{\jmath}$, wingspan $21 \mathrm{~mm} ; 2$-4) Trentino Alto Adige, PIRA 489 , wingspan (WS) $20 \mathrm{~mm}$. Delplanqueia inscriptella (B): 1-3) Sardinia, PIRA 503 , WS 18 mm; 2-4) Sardinia, PIRA 482 , WS $17 \mathrm{~mm}$. inscriptella to $105 \pm 6 \%$ (Range: 85 to $119 \%$ ) when considering all specimens together. $D$. inscriptella showed higher values of $C A$ ratio than dilutella (Mann-Whitney $\mathrm{U}$ test, $C A$ ratio, $\mathrm{N}_{\text {inscriptella }} 49$, $\left.\mathrm{N}_{\text {dilutella }}=18, \mathrm{U}=10.00, \mathrm{Z}=6.10, \mathrm{P}<0.0001\right)$.

As the wingspan concerns, the values of WS dilutella males were on average equal to $20.00 \pm 1.19 \mathrm{~mm}$ (Mean value $\pm S D$; Range: $18 \mathrm{~mm}$ to $22 \mathrm{~mm}$ ) and in inscriptella to $18.84 \pm 1.18 \mathrm{~mm}$ (Range: 17 to $21 \mathrm{~mm}$ ) when considering all specimens together. Delplanqueia dilutella showed higher values of WS than inscriptella (Mann-Whitney $\mathrm{U}$ test, wingspan, $\mathrm{N}_{\text {inscriptella }} 49$, $\left.\mathrm{N}_{\text {dilutella }}=18, \mathrm{U}=230.50, \mathrm{Z}=-2.98, \mathrm{P}<0.0001\right)$. When grouping the males for regions and for localities in which the two species are sympatric, such as Vallemare, the results showed variability in $C A$ ratio and WS and therefore an overlap of morphological data between the studied species (Table 1).

\section{Females}

In both species, females have a pair of signa in the corpus bursae (Figure 1). These have different lengths and the values of their ratio ( $S$ ratio) in Delplanqueia dilutella were on average equal to $55.77 \pm 4.37 \%$ (Range: 52 to $64 \%$ ) and in D. inscriptella to $70 \pm 5.3$ $\%$ (Range: 60 to $80 \%$ ) when considering all specimens together. $D$. inscriptella showed higher values of $S$ ratio than dilutella (Mann-Whitney $\mathrm{U}$ test, $S$ ratio, $\mathrm{N}_{\text {inscriptella }}=17, \mathrm{~N}_{\text {dilutella }}=6, \mathrm{U}=2.00$, $\mathrm{Z}=3.43, \quad \mathrm{P}=0.0006$ ). Females show a similar wingspan $\left(\mathrm{WS}_{\text {dilutella }}=18.50 \pm 1.38 \mathrm{~mm}, \mathrm{~N}=6 ; \mathrm{WS}_{\text {inscriptella }}=17.59 \pm 1.54 \mathrm{~mm}\right.$, $\mathrm{N}=17$; Mann-Whitney U test, NS).

\section{Distribution of the studied specimens in Italy}

The distribution map of the studied specimens revealed that the North and especially the Northern East Italy was studied a lot in the past by several collectors (Hartig 1958, Figure 2) and the prevailing species in this area was $D$. dilutella; this species therefore was recorded in Piedmont and Lombardy, and also in Abruzzo.

As D. inscriptella concerns, it was recorded mainly in Central Italy and Sardinia. In Sicily we examined only two specimens, one attributed to $D$. dilutella (Palermo, Hartig's collection (MZUR) and the other to D. inscriptella (Zappulla, ME). As the entomological card under the specimen from Palermo reveals (Figure 1, right), the original collector was Mariani but it was changed in Dannehl and unfortunately the collecting year is incomplete, i.d., 193 (sic!).

Delplanqueia dilutella and D. inscriptella, while in some localities they live separately (e.g., Liguria and Sardinia, D. inscriptella), in others were coexistent as in Trentino (at Mattarello (sic!), in Umbria and Latium (at low altitude). In Latium, precisely at Vallemare (RI), D. dilutella and D. inscriptella live together however the first seems an elusive species and is little attracted to lamp (Mario Pinzari, personal observation). As evidence of this, in Pinzari's collection there are

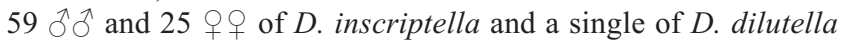
(Figure 1). They were collected from 1989 to 2017 in the context of a wide ongoing survey on lepidopterofauna (Pinzari, 2009, 2016a, 2016b; Pinzari and Sbordoni, 2013; Pinzari et al., 2013, 2015, 2016b, 2017b, 2018, 2019).

Therefore, we did not find any specimen attributable to Delplanqueia cortella. The historical specimens collected by Hartig in Sardinia were collected in the same localities and dates mentioned by Hartig and Amsel (1951) and were placed in Hartig's collection (MZUR) as cortella. After our study, all are identified as Pempeliella matilella (Leraut, 2001). 


\section{Discussion}

Our study revealed that all specimens identified in the past as Pempeliella subornatella were Delplanqueia dilutella and Pempeliella dilutella were Delplanqueia inscriptella.

The original collocation of the studied specimens in Hartig's collection (MZUR) showed that both Hartig and his contemporary entomologists were able to well distinguish the species belong to the studied group without the examination of genitalia. On the basis of habitus, it is indeed possible to recognize dilutella from inscriptella (Figure 1). The wing pattern of fresh males of $D$. dilutella is like that typical of subornatella illustrated by Slamka (1997). The wings background colour of inscriptella is always characterized by a more or less strong presence of pompeian red, turned to brick red in the historical specimens (Figure 1); this is even in the specimens with a more marked design. Therefore, light scales in dilutella are very widespread even outside of the lines of wing design; the scales are white in dilutella while gray colored in inscriptella.

Genitalia and especially the lengths of cornutus and aedeagus that are similar in inscriptella e significantly shorter in dilutella, as illustrated or explicitly mentioned by different authors (Leraut,
2001; Buhl et al., 2016; Schmid, 2016; Plant et al., 2017; Slootmaekers et al., 2018), support and confirm the determination of the species. The variability of the genital features (e.g., $C A$ ratio), indicates that the criterion cannot be applied to a single individual but it could be valid only applying to on an adequate number of specimens from the same locality (see, for example, the data from Vallemare in Lazio, Table 1, Figure 1). As wingspan concerns, in European populations, WS of inscriptella is on average larger than dilutella (Leraut, 2001; Buhl et al., 2016), while in Italian populations it is exactly the inverse (Table 1). Females of the two species have similar wingspan and are smaller than males. For the determination of females on the basis of the habitus, the same criteria as those of the males apply. However, if the specimens under the study are females, it is easier to make mistakes in the identification of the species, because the differences between species are more attenuated in females (Figure 1).

According to different authors, the ratio between the lengths of signa seems to be decisive for identifying the species but also in this case this characteristic is actually valid in the determination of the species comparing large samples from the same natural population and less useful for the examination of few individuals (Table 1). Neither the amplitude of signa is a good and convincing diagnostic
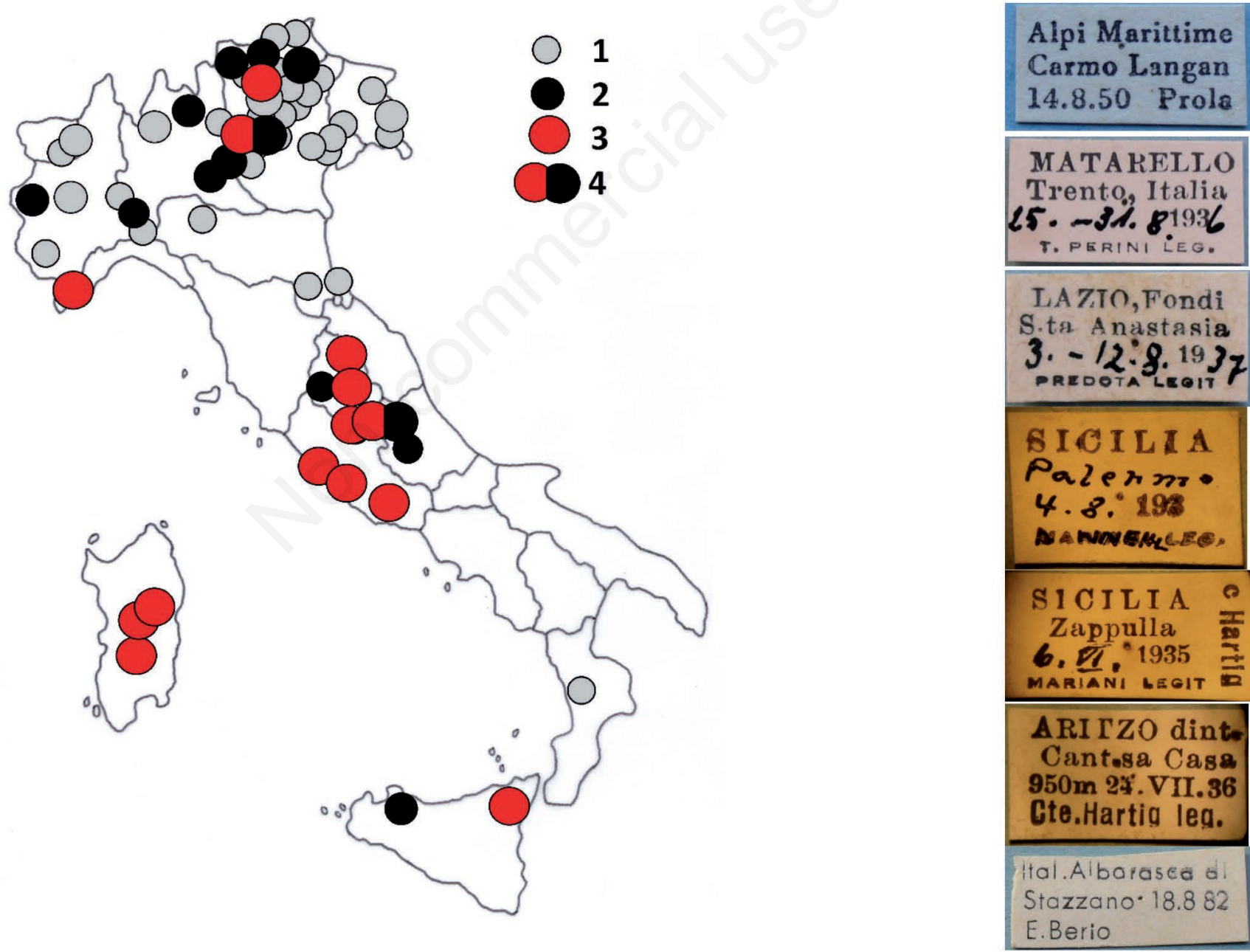

Figure 2. Distribution of the genus Delplanqueia in Italy after our study: 1) unverified quotations; 2) D. dilutella; 3) D. inscriptella; 4) $D$. dilutella and $D$. inscriptella. On the right we show some historical entomological cards (from top to bottom) by C. Prola; T. Perini; C. Predota; F. Dannehl; M. Mariani; F. Hartig; E. Berio. 
character (Figure 1) due to the wide variability of female genital features. Our experience suggests that, in addition to the length of the two signa, it is important to observe their mutual position. Leraut (2001), and recently Buhl et al. (2016) illustrated female genitalia of inscriptella with crossed signa while dilutella with parallel signa. We have indeed observed that in all studied specimens of inscriptella the end of the longer signa twists on the other shorter; in other words, the two signa appear skewed and crossed to the observer. This feature is always present even in the cases where the ratio between the signa leaves some doubts. In dilutella the two ends of signa instead do not roll up. Thus, the mutual position of signa and $\mathrm{S}$ ratio may be good diagnostic features but not considered alone.

Also, the specimens placed in Pempeliella cortella in Hartig's collection were well determined by Hartig as different from the other two species but were classified as Delplanqueia matilella (Pinzari and Pinzari, 2019). Of five Italian paratypes of D. matilella $1 \hat{\delta}$ and 3 q 0 were collected by Hartig and $1 q$ by Amsel in Sardinia and preserved by Leraut (2001). In the Hartig's collection (MZUR) is preserved a good sample of 27 specimens with collocation under $D$. cortella that we examined. The jagged antennae of male, the totally different genitalia and the habitus leave no doubts about the determination of the species: D. matilella. The sample site of all specimens and almost all the sampling dates coincide with the paratypes. Accordingly, we can say with certainty that the quote about $D$. cortella by Hartig and Amsel (1951) for Sardegna concerned D. matilella, later described by Leraut (2001).

Hartig and Amsel (1951) also mentioned the presence of Pempelia dilutella in Sardinia at the localities and dates: Aritzo 420.VII; Santoru 8.VI; Belvì 6.VIII; Desulo 7.VII. We examined 1 from Aritzo, 9.VII.1936 in Hartig's collection with collocation under $P$. dilutella. Our study revealed that this specimen was $D$. inscriptella. Also, other two males and a female placed in $P$. dilutella from Isili and $\mathrm{Ct}$. Fontanamela are $D$. inscriptella on basis of their habitus (short wingspan: $\widehat{\jmath}, 18.6 \mathrm{~mm}$;,$+ 17 \mathrm{~mm}$ ) and genitalia (Table 1, Figure 1).

As the distribution in Italy concerns, Hartig (1958) already pointed out that $D$. dilutella (ex subornatella) was spread from the valleys up to the middle mountain in two generations in May-June and then isolated in August-September; it was very isolated on the other hand in the Oltrebrennero area ("era diffusa dalle valli fino alla media montagna in due generazioni nel V-VI e poi isol(ate) nella VIII-IX. Molto isolate invece nel settore dell'Oltrebrennero", Hartig, 1958). About D. inscriptella (ex dilutella), the author writes "somewhat more diffuse but less frequent, in two generations from the end of May to the beginning of July and from August-September, often attracted to the lamp" ("alquanto più diffusa ma meno frequente, in due generazioni dalla fine $V$ - principio VII e dall'VIII - IX, spesso al Lume", Hartig, 1958).

These observations concerning Trentino Alto Adige are clearly confirmed in the map of Figure 2, as further proof that the specimens examined are part of those used by Hartig for his publication in the 50s (Hartig, 1958). In this work, it is interesting the note on inscriptella that this moth often comes to light because it confirms our observations in Vallemare; here, we collected indeed at the lumen dozens of inscriptella and only one dilutella. This fact let us suppose that even dilutella is more widespread in Italy than it seems.

\section{Conclusions}

We revealed the presence in Italy of two species of the genus Delplanqueia Leraut, 2001: dilutella and inscriptella. Our findings showed that cortella is not present in Sardinia and the specimens cited by Hartig were Pempeliella matilella (Pinzari and Pinzari, 2019). D. dilutella is quite common in northern Italy but also in the center and in Sicily. D. dilutella is very elusive, perhaps not very attracted to light. D. inscriptella is present in Liguria and in Trentino Alto Adige, clearly more widespread in the center of Italy, also in Sicily and Sardinia. In Latium (Vallemare) and in Trentino Alto Adige (Matarello) the two species coexist in the same environment.

\section{References}

AGASSIZ D., 2015 - Delplanqueia inscriptella (Duponchel, 1836) a sister species of D. Dilutella (Denis \& Schiffermüller, 1775) (Lepidoptera: Pyralidae) resident in Britain. - Entomol. Rec. J. Var. 127: 185-189.

ASSELBERGS J.E.F., SEGUNA A., SAMMUT P., 2008 - Recent records of Pyraloidea species new to Malta, including two species new to the European fauna (Lepidoptera: Pyraloidea). - Shilap Revta. Lepid. 36: 465-471.

BALDIZZONE G., 1996 - I microlepidotteri del Parco Naturale del Mont Avic e zone limitrofe (Valle d'Aosta - Val Chalamy - Alpi Graie orientali). - Revue Valdôtaine d'Histoire Naturelle 50: 55-141.

BALDIZZONE G., 2005 - I Microlepidotteri del Parco Naturale Alpi marittime (Italia, Piemonte) (Lepidoptera). - Bollettino Museo Regionale di Scienze Naturali 22: 1-318.

BALDIZZONE G., CABELLA C., FIORI F., VARALDA P.G., 2013 - I Lepidotteri del Parco Naturale delle Capanne di Marcarolo. - Memorie dell'Associazione Naturalistica Piemontese 12: 1-349.

BASSI G., PASSERIN D'ENTREVES P., SPEIDEL W., ZANGHERI S., 1995 - Lepidoptera Pyraloidea. In: MINELLI A., RUFFO S., LA POSTA S., eds. Checklist delle specie della fauna italiana, 87. Bologna, BO: Calderini pp. 1-28.

BUHL O., FALCK P., KARSHOLT O., LARSEN K., VILHELMSEN F., 2016 - Records of Microlepidoptera from Denmark in 2014 (Lepidoptera). - Entomol. medd. 83: 88-109.

BURMANN K, 1995 - Beitrage zur Microlepidopteren-Fauna Tirols. XIX. Pyralidae-Phycitinae (Insecta: Lepidoptera). Ber. Nat.-med. Ver. Innsbruck 82: 297-309.

CURÒ A., 1880 - Saggio di un catalogo dei Lepidotteri d'Italia. Boll. Soc. Entomol. Ital. 12: 51-92.

DELLA BEFFA G., 1941 - I Piralidi della catena alpina. - Boll. Lab. Sperim. Osserv. Fitopatol. Turin 17: 3-34.

DEUTSCH H., 2006 - Contribution to the knowledge of the Lepidoptera of Friuli Venezia Giulia (North Italy). Part I: Province of Udine (Carnic Alps, Carnic Pre-Alps, Upper Tagliamento river). - Gortania 27: 227-298.

FAZEKAS I., 1996. - Contribution to the knowledge of the microlepidoptera-fauna der Friuli-Venezia Giulia (Lepidoptera). - Gortania 18: 215-228.

HARTIG F., 1939 - Contributo alla conoscenza della Fauna lepidotterologica dell'Italia centrale. - Mem. Soc. Entomol. Ital. 18: 186-98.

HARTIG F., 1956 - Prodromus dei Microlepidotteri della Venezia Tridentina e delle regioni adiacenti. - Studi Trentini di Scienze Naturali 33: 89-148.

HARTIG F., 1958 - Microlepidotteri della Venezia Tridentina e delle regioni adiacenti. - Studi Trentini di Scienze Naturali 35: 106-268.

HARTIG F., AMSEL H.G., 1951 - Lepidoptera sardinica. - Fragm. Entomol. 1: 3-159.

HUEMER P., 1997 - Lepidoptera in the area of the Dealpine rivers 
Meduna and Tagliamento (Friuli-Venezia Giulia, northernItaly). - Gortania 18: 201-214.

HUEMER P., 2002 - Biomonitoring der Schmetterlingsfauna in Waldstandorten Südtirols und Trients (Lepidoptera). - Linz. Biol. Beitr. 34: 199-264.

HUEMER P., 2004. Biodiversitat von Schmetterlingen (Lepidoptera) an der Etsch (Sudtirol). - Gredleriana 4: 247-294.

HUEMER P., MORANDINI C., 2008 - Contributo alla conoscenza dei Lepidotteri dell'area di Valle Vecchia (Caorle, Venezia) con particolare riguardo agli aspetti conservazionistici. - Gortania 30: 221-54.

LERAUT P. 2001 - Contribution à l'étude des phycites paléarctiques (Lepidoptera, Pyralidae, Phycitinae). - Rev. Fr. Entomol. 23: 129-41.

LERAUT P., 2014 - Moths of Europe. Vol. 4: Pyralids 2. N.A.P. Editions

MARIANI M., 1939 - Fauna Lepidopterorum Siciliae (Catalogo ragionato). - Mem. Soc. Entomol. Ital. 17: 129-87.

PASTORÁLIS G., LIŠKA J., ELSNER G., ŠUMPICH J., RICHTER I., TOKÁR Z., ENDEL B., SKYVA J., 2017 Eleven Lepidoptera species new to the fauna of Slovakia. - Fol. Faun. Slovaca 22: 19-29.

PINZARI M., 2009 - A Comparative Analysis of Mating Recognition Signals in Graylings: Hipparchia statilinus vs. H. semele (Lepidoptera: Nymphalidae, Satyrinae). - J. Insect Behav. 22: 227-44.

PINZARI M., PINZARI M., ZILLI A., 2010 - Deep lepidopterological exploration of Mt Cagno and surroundings (Central Italy), a restricted mountain Massif and hotspot for butterfly and moth diversity. - Boll. Assoc. Rom. Entomol. 65: 3-383.

PINZARI M., SBORDONI V., 2013 - Species and mate recognition in two sympatric Grayling Butterflies: Hipparchia fagi and H. hermione genava (Lepidoptera). - Ethol. Ecol. Evol. 25: 28-51. doi: 10.1080/03949370.2012.703244.

PINZARI M., PINZARI M., ZILLI A., 2013 - Additions and corrections to the Lepidoptera fauna of Mt Cagno and surroundings (Central Italy), with first records of Caloptilia honoratella and Buvatina stroemella from Italy (Lepidoptera). - Boll. Assoc. Rom. Entomol. 68: 51-72.

PINZARI M., PINZARI M., ZILLI A., 2015 - Additions to the Lepidoptera fauna of Mt Cagno and surroundings (Central Italy) with twelve interesting species for the Italian fauna (Lepidoptera). - Boll. Assoc. Rom. Entomol. 70: 105-115.

PINZARI M., 2016a - Deraeocoris schach, a new predator of Euphydryas aurinia and other heteropteran feeding habits on caterpillar web (Heteroptera: Miridae; Lepidoptera: Nymphalidae). - Fragm. Entomol. 48: 77-81.

PINZARI M., 2016b - Scythris clavella (Zeller, 1855) in Italy (Lepidoptera, Gelechioidea, Scythrididae). - Journal of Entomological and Acarological Research 48: 301-303.

PINZARI M., ZERUNIAN Z., PINZARI M., 2016a Microlepidotteri di Assisi (Italia) (Lepidoptera). - Boll. Assoc. Rom. Entomol. 71: 107 - 200.

PINZARI M., PINZARI M., SBORDONI V., 2016b - Egg laying behaviour, host plants and larval survival of Euphydryas aurinia provincialis (Lepidoptera Nymphalidae) in a Mediterranean population (Central Italy). - Boll. Soc. Ent. Ital. 148: 121-140.

PINZARI M., MALTZEFF P., PINZARI M., 2017a - I Microlepidotteri della Tenuta Presidenziale di Castelporziano (Roma, Italia)(Lepidoptera). - Boll. Assoc. Rom. Entomol. 72: 31-84.

PINZARI M., PINZARI M., SBORDONI V., 2017b - Notes on Life-History of Erycia furibunda (Diptera: Tachinidae), a par- asitoid of Euphydryas aurinia provincialis (Lepidoptera: Nymphalidae). - Redia 100: 81-87.

PINZARI M., SANTONICO M., PENNAZZA G., MARTINELLI E., CAPUANO R.M., PAOLESSE R., DI RAO M., D'AMICO A., CESARONI D., SBORDONI V., DI NATALE C. 2018a Chemically mediated species recognition in two sympatric Grayling butterflies: Hipparchia fagi and Hipparchia hermione (Lepidoptera: Nymphalidae, Satyrinae). Plos One 13: e0199997.

PINZARI M., ZERUNIAN Z., PINZARI M., 2018b - Is the alien species Clepsis peritana (Lepidoptera: Tortricidae) settling in Italy? - Journal of Entomological and Acarological Research 50(7551): 1-3.

PINZARI M., CIANFERONI F., FABIANI A., DIOLI P., 2019a Predation by nymphs of Picromerus bidens (Heteroptera: Pentatomidae, Asopinae) on caterpillars of Euphydryas aurinia provincialis (Lepidoptera: Nymphalidae) in Italy. - Redia 102, accepted on 7th March, 2019.

PINZARI M., 2019 - Phylloneta sisyphia (Araneae: Theridiidae), a predator of larvae of Euphydryas aurinia (Lepidoptera: Nymphalidae) and its parasitoid Erycia furibunda (Diptera: Tachinidae). - Acta Zoologica Bulgarica, 71(2): 195-200.

PINZARI M., PINZARI M., SBORDONI V., 2019b - Make it simply: the mating behaviour of Euphydryas aurinia provincialis (Lepidoptera: Nymphalidae). - The European Zoological Journal 86(1): 220-232.

PINZARI M., PINZARI M., 2019 - Genus Pempeliella Caradja, 1916 and P. bayassensis Leraut, 2001 (Lepidoptera, Pyralidae) in Italy. - ZooKeys 854: 131-144.

PLANT C.W., BESHKOV S., JAKSIC P., NAHIRNIC A., 2017 A contribution to knowledge of the balkan Lepidoptera. Some Pyraloidea (Lepidoptera: Crambidae \& Pyralidae) encountered recently in southern Serbia, Montenegro, the Republic of Macedonia and Albania. University Thought (Publication in Natural Sciences) 7: 1-27.

ROBERTI D., FRILLI F., PIZZAGHI W., 1965 - Contributo alla conoscenza dell'entomofauna del Piacentino (Specie raccolte nel decennio 1955- 1964). - Entomologica (Annali di Entomologia Generale ed Applicata) 1: 1-120.

SCALERCIO S., 2016 - Interesting records of Pyraloidea from southern Italy, especially from forested habitats (Lepidoptera: Pyralidae, Crambidae). - Shilap Revta. Lepid. 44: 433-442.

SCHMID J., 2016 - Delplanqueia inscriptella (Duponchel, 1836) new for the fauna of Switzerland and confirmation of the Swiss occurrence of Pempeliella bayassensis Leraut, 2001 (Lepidoptera: Pyralidae, Phycitinae). - Entomo Helvetica 9: 35-39.

SLAMKA F., 1997 - Die Zunslerartigen (Pyraloidea) Mitteleuropas. Bratislava, $112 \mathrm{pp}$.

SLOOTMAEKERS D., SNYERS C., WULLAERT S., 2018 Ephestia welseriella and Delplanqueia inscriptella (Lepidoptera: Pyralidae, Phycitinae), new to the Belgian fauna. - Phegea 45: 91-3.

SPEIDEL W., SEGERER A., NUSS M., 2013 - Fauna Europaea: Pyralidae; 2013. In: Karsholt O. \& van Nieukerken E. J. (Eds), Fauna Europaea, moths. Version 2.6. Available from: www.fauna-eu.org, accessed on January 13, 2019.

TURATI E., 1879 - Contribuzione alla Fauna entomologica Lombarda. Lepidotteri. - Boll. Soc. Ent. Ital. 11: 153 - 208, Tav. VII-VIII.

TURATI E., VERITY R., 1911 - Faunula Valderiensis nell'alta Valle del Gesso (Alpi Marittime). Boll. Soc. Ent. Ital. 43: 168-233.

WITTLAND W., SELIGER R., 2016 - Delplanqueia dilutella (Denis \& Schiffermüller, 1775) und Delplanqueia inscriptella (Duponchel, 1836) in Nordrhein-Westfalen und Rheinland- 
Pfalz mit Anmerkungen zur Gesamtverbreitung (Lep., Pyralidae, Phycitinae). Melanargia 28: 74-82.

YLLA J., GASTÓN J., MACIÀ R., 2019 - El género Pempeliella sensu lato en la Península Ibérica e Islas Baleares, descripción de Huertasiella Ylla, Gastón \& Macià, gen. n. y designación del neotipo de Pempelia enderleini Rebel, 1934 (Lepidoptera: Pyralidae, Phycitinae). - Shilap Revta. lepid., 47: 129-159.
ZANGHERI P. 1923 - Fauna di Romagna. Lepidotteri (Prima contribuzione). - Mem. Soc. Entomol. Ital. 2: 13-49.

ZANGHERI P., 1950 - Fauna di Romagna. Microlepidotteri: Pterophoridae e Pyralidae. - Boll. Assoc. Rom. Entomol. 5: 9-15. ZERNY H., 1943 - Eine Falterausbeute aus Sizilien. II. Teil Mikrolepidopteren. - Zeitschrift der Wiener Entomologischen Gesellschaft 28: 135-140, 156-159, 1 tfl. 